\title{
OPTIMALISASI PENGGUNAAN BIJI KLUWAK (Pangium edule Reinw)TERHADAP MUTU IKAN PATIN JAMBAL SIAM (Pangasius sucthi) SEGAR SELAMA PENYIMPANAN PADA SUHU KAMAR
}

\author{
Eka Ramadhani, Chainul Fiffah, Rahmiwati Hilma
}

\author{
Jurusan kimia FMIPA Universitas Riau \\ Jurusan kimia FMIPA Universitas Muhammadiyah Riau \\ e-mail: ramadhanieka81@yahoo.co.id
}

\begin{abstract}
ABSTRAK
Ikan merupakan sumber pangan yang cepat mengalami pembusukan, sehingga perlu usaha untuk mengawetkannya. Salah satu bahan pengawet alami yang digunakan adalah kluwak. Kluwak mengandung senyawa antioksidan dan senyawa yang memiliki aktivitas antibakteri. Pengawetan dilakukan dengan menggunakan konsentrasi $\mathrm{P}_{0}(0 \%$ biji kluwak dan garam $2 \%), \mathrm{P}_{1}(2 \%$ biji kluwak dan garam $2 \%), \mathrm{P}_{2}(4 \%$ biji kluwak dan garam 2\%), $\mathrm{P}_{3}(6 \%$ biji kluwak dan garam $2 \%)$ dan melihat nilai mutu ikan patin dari sifat organoleptik (rupa, bau, tekstur, dan rasa) serta nilai gizi protein yang dianalisis dengan metode Kjeldahl setelah disimpan pada suhu kamar selama 6 hari. Dari analisis variansi DMRT (Duncan's Multiple Range Test) perlakuan $\mathrm{P}_{2}\left(4 \%\right.$ biji kluwak dan garam 2\%) dan $\mathrm{P}_{3}(6 \%$ biji kluwak dan garam $2 \%$ ) tidak berbeda nyata terhadap nilai organoleptik (rupa, bau, tekstur, dan rasa) serta nilai kadar protein, tetapi $\mathrm{P}_{2}$ dan $\mathrm{P}_{3}$ berbeda nyata dengan perlakuan $\mathrm{P}_{0}$ dan $\mathrm{P}_{1}(\mathrm{P}<0,05)$, sehingga $\mathrm{P}_{2}$ adalah perlakuan terbaik yang mampu dalam mempertahankan mutu ikan patin setelah disimpan pada suhu kamar selama 4 hari.
\end{abstract}

Kata kunci: ikan patin jambal siam, kluwak, fermentasi anaerob, organoleptik.

\section{PENDAHULUAN}

Ikan patin jambal siam merupakan salah satu jenis ikan yang paling banyak dibudidayakan di daerah Riau. Ikan ini dipelihara di kolam, keramba dan waduk yang tersebar di Riau daratan pada umumnya. Produksi ikan ini juga meningkat seiring dengan peningkatan areal budidaya, pada tahun 2007 jumlah produksi ikan jambal siam mencapai angka 1.751,3 ton, sedangkan pada tahun 2010 meningkat menjadi 1.979,8 ton (Dinas Perikanan Provinsi Riau, 2010).

Hasil perikanan merupakan produk yang mempunyai nilai gizi yang tinggi terutama disebabkan oleh kandungan proteinnya. Selain rasanya yang enak, nilai protein daging patin juga tergolong tinggi, mencapai $68,6 \%$, lemak 5,8\%, abu 3,5\%, kadar air $59,3 \%$ dan kandungan lemaknya dilaporkan semakin tinggi dengan semakin besarnya ukuran ikan (Amri dan Khairuman, 2008).
Disisi lain produk hasil perikanan juga mempunyai kelemahan yaitu cepat sekali mengalami proses pembusukan dan penurunan mutu yang disebabkan oleh kegiatan enzimatis dalam tubuh ikan itu sendiri serta pertumbuhan mikroorganisme. Oleh karena itu perlu upaya untuk mengawetkan bahan makanan tersebut sehingga dapat diterima konsumen dalam keadaan yang masih layak dikonsumsi (Purwani dan Muwakhidah, 2008).

Pengawetan ikan dapat dilakukan dengan menambahkan bahan pengawet alami maupun kimiawi. Salah satu cara yang paling mudah dan praktis adalah dengan metode penggunaan suhu rendah, ataupun dengan penggunaan es, namun dalam penerapan metode suhu rendah ini masih banyak ditemukan kendala yang dihadapi oleh para nelayan diantaranya sulitnya para nelayan dalam menyediakan es bila jumlah hasil tangkapan cukup banyak dan harga es 
semakin mahal (Mangunwardoyo, Lily dan Endang, 2008).

Beberapa jenis bahan pengawet kimia yang sering digunakan pada ikan bisa membahayakan kesehatan, seperti formalin atau boraks. Akhir-akhir ini terdapat kecenderungan untuk menggunakan bahan pengawet yang berasal dari tumbuhan karena dianggap lebih aman. Beberapa penelitian juga membuktikan bahwa bahan alami cukup efektif sebagai pengawet makanan, diantaranya adalah rempahrempah. Aktivitas rempah-rempah sebagai pengawet disebabkan fungsinya sebagai antioksidan dan antimikroba, sebagai contoh kunyit, laos, jahe, lengkuas (Purwani dan Muwakhidah, 2008).

Salah satu alternatif pengganti es sebagai pengawet ikan adalah dengan menggunakan buah kluwak. Kluwak selain sebagai bumbu masak dapur, biji kluwak digunakan sebagai pengawet alami ikan segar. Biji kluwak mengandung senyawa antioksidan dan antibakteri. Senyawa antioksidan dalam biji kluwak antara lain: vitamin $\mathrm{C}$ dan $\beta$ karoten. Sedangkan senyawa yang memiliki aktivitas antibakteri yakni asam sianida, asam hidnokarpat, asam khaulmograt, asam gorlat, dan tanin. Khusus senyawa asam sianida dan tanin, kedua senyawa inilah yang mampu memberikan efek pengawetan terhadap ikan (Hangesti, 2006).

Hasil penelitian Hangesti (2006), yang telah dilakukan adalah penggunaan $2 \%$ biji kluwak dan 2\% garam untuk mempertahankan kesegaran ikan kembung. Dilatarbelakangi hal tersebut diatas dan belum diketahuinya pengaruh penggunaan biji kluwak dengan menggunakan konsentrasi $\mathrm{P}_{0}(0 \%$ biji kluwak dan garam $2 \%), \mathrm{P}_{1}$ (2\% biji kluwak dan garam $\left.2 \%\right), \mathrm{P}_{2}$ (4\% biji kluwak dan garam 2\%), dan $\mathrm{P}_{3}(6 \%$ biji kluwak dan garam 2\%) terhadap mutu dan nilai gizi protein pada ikan patin jambal siam segar, maka penulis tertarik untuk melakukan penelitian tentang "Optimalisasi Penggunaan Biji Kluwak (Pangium edule Reinw) Terhadap Mutu Ikan Patin Jambal Siam (Pangasius sucthi) Segar Selama Penyimpanan pada Suhu Kamar".

\section{METODOLOGI PENELITIAN Waktu dan Tempat}

Penelitian dilaksanakan pada bulan Mei -Juni tahun 2012 di Laboratorium Unit Pelaksana Teknis (UPT) Pengujian Dinas Pekerjaan Umum Provinsi Riau Jalan Jendral Sudirman No. 197 Pekanbaru.

\section{Bahan dan Alat}

Bahan yang digunakan adalah:

Bahan-bahan yang digunakan dalam penelitian adalah ikan jambal siam sebanyak 24 ekordengan berat rata-rata 20 gram/ekor yang diperoleh dari pembibitan perikanan di jalan pasir putih-Pekanbaru, buah kluwak sebanyak $1 \mathrm{~kg}$ yang didapatkan dari pasar tradisional Pekanbaru, garam komersial, dan bahan yang digunakan dalam analisis protein yaitu: $\mathrm{H}_{2} \mathrm{SO}_{4}$ pekat, campuran katalis selen, batu didih, larutan asam borat $\left(\mathrm{H}_{3} \mathrm{BO}_{3}\right.$ $4 \%$ ), indikator campuran (larutan indikator methyl red (MR) dan bromocresol green (BCG)), larutan $\mathrm{NaOH} \mathrm{30 \% ,} \mathrm{indikator}$ fenolftalein $1 \%$, larutan $\mathrm{HCl} 0,1 \mathrm{~N}$, dan akuades.

\section{Alat}

Alat-alat yang digunakan dalam penelitian adalah wadah plastik tertutup sebagai tempat penyimpanan ikan, labu Kjeldahl $100 \mathrm{~mL}$, pemanas listrik/alat destruksi dilengkapi dengan penghisap asap, alat penyulingan/destilasi, neraca analitik, dan peralatan gelas yang biasa digunakan di laboratorium.

\section{Metode dan Analisis Data Penelitian}

Metode yang digunakan adalah metode eksperimen yaitu melakukan pengawetan 
ikan patin jambal siam menggunakan biji kluwak yang disimpan pada suhu kamar.

Analisis data yang digunakan adalah Rancangan Acak Kelompok Lengkap (RAKL). Perlakuan yang diberikan adalah penggunaan biji kluwak dengan konsentrasi P0 (0\% kluwak), P1 (2\% kluwak), P2 (4\% kluwak) dan P3 (6\% kluwak) yang masingmasing diberi garam sebanyak $2 \%$. Sedangkan sebagai kelompok adalah lama penyimpanan yaitu 1 hari, 2 hari, 3 hari, 4 hari, 5 hari dan 6 hari. Satuan percobaan yang digunakan adalah 24 ekor ikan patin jambal siam dengan berat rata-rata 20 gram/ekor.Adapun model matematis yang digunakan menurut Gasperz (1991) adalah sebagai berikut:

$$
Y i j=\mu+\alpha i+\beta j+\varepsilon i j
$$

Dimana:

$Y i j=$ Pengamatan pada perlakuan ke-i dan kelompok ke-j

$\mu=$ Nilai tengah dari seluruh perlakuan/rataan umum

$\alpha i=$ Pengaruh dari perlakuan ke-i

$\beta j=$ Pengaruh dari perlakuan ke- $\mathrm{j}$

$\varepsilon i j=$ Pengaruh acak pada perlakuan ke-I dan kelompok ke-j

\section{Prosedur Penelitian}

\section{Pembuatanpengawet kluwak}

a. Dicuci biji buah picung segar, kemudian direbus selama satu jam, lalu dikeringkan.

b. Disiapkan wadah tertutup, diletakkan abu sekam di dasar wadah, dimasukkan biji buah picung, dan ditutup kembali dengan abu sekam hingga seluruh permukaan tertutup abu.

c. Didiamkan selama lebih kurang 40 hari.

d. Dibersihkan, lalu akan diperoleh biji kluwak kecoklatan, dan kluwak siap digunakan.

\section{Pengawetan ikan patin jambal siam}

a. Biji kluwak dipecahkan, lalu diambil daging buah kluwak dengan cara mencongkel daging yang menempel pada cangkang.

b. Daging buah kluwak dihaluskan.

c. Sementara itu ikan jambal siam disiangi dengan membuang insang dan isi perut lalu dicuci bersih kemudian ditiriskan.

d. Daging kluwak yang telah dihaluskan tadi ditimbang sesuai kebutuhan berdasarkan konsentrasi P0 $(0 \%$ biji kluwak dan garam 2\%), P1 (2\% biji kluwak dan garam 2\%), P2 (4\% biji kluwak dan garam 2\%), dan P3 (6\% biji kluwak dan garam 2\%) dari berat ikan.

e. Dilumurkan campuran kluwak dan garam pada permukaan tubuh, dan di dalam perut ikan patin jambal siam segar.

f. Disimpan dalam wadah plastik tertutup selama 6 hari (1 hari=24 jam).

g. Terakhir penyimpanan pada suhu kamar (setiap hari dibuka selama

h. 5 menit).

\section{Penilaian organoleptik}

Penilaian organoleptik dilakukan oleh 10 orang panelis belum terlatih. Panelis dalam penelitian ini adalah analis yang bekerja di Unit Pelaksana Teknis (UPT) Pengujian Dinas Pekerjaan Umum Provinsi Riau. Penilaian ini bertujuan untuk mengamati rupa, bau, tekstur, dan rasa ikan menggunakan skor/penilaian organoleptik yang telah disediakan dengan skala 1-5. Untuk uji rasa ikan terlebih dahulu direndam dalam air bersih selama 15 menit kemudian dikukus selama 20 menit.

\section{Analisis kadar protein (SNI 7474:2009) Tahap destruksi}

a. Ditimbang 2,0-2,2 gr contoh ke dalam labu Kjeldahl $100 \mathrm{~mL}$, ditambahkan 1 gr campuran katalis selen, 8 - 10 batu didih 
dan $25 \mathrm{~mL} \mathrm{H}_{2} \mathrm{SO}_{4}$ pekat ke dalam labu Kjeldahl.

b. Campuran dipanaskan dalam lemari asam yang dilengkapi alat destruksi dengan unit pengisap asap sampai mendidih dengan suhu $400^{\circ} \mathrm{C}$ dan larutan menjadi jernih kehijau-hijauan (sekitar 2 jam).

c. Dibiarkan dingin, kemudian diencerkan dengan akuades secukupnya. ditambahkan 75 mL larutan $\mathrm{NaOH} 30 \%$ (diperiksa dengan indikator fenolftalein sehingga campuran menjadi basa $\mathrm{pH}$ 9).

\section{Tahap destilasi}

a. Dipipet $50 \mathrm{~mL}$ larutan $\mathrm{H}_{3} \mathrm{BO}_{3}$ $4 \%$ yang telah dicampur indikator campuran kedalam erlenmeyer.

b. Didestilasi larutan yang di labu Kjeldahl dengan larutan yang di erlenmeyer selama 20 menit dengan suhu $34^{\circ} \mathrm{C}$, hingga volume penampung destilat telah mencapai $150 \mathrm{~mL}$.

c. Dibilas ujung pendingin dengan akuades.

\section{Tahap titrasi}

a. Dititar larutan campuran destilat dengan larutan $\mathrm{HCl} 0,1 \mathrm{~N}$. Akhir titrasi ditandai dengan perubahan warna larutan dari biru menjadi merah muda.

b. Dikerjakan juga untuk penetapan blanko. Perhitungan:

Kadar protein $=\frac{\left(V_{1}-V_{2}\right) \times N \times 14,008 \times 6,25}{W} \times 10$

Dimana:

$\mathrm{W}=$ Bobot cuplikan (mg)

$\mathrm{V}_{1} \quad=$ Volume $\mathrm{HCl} 0,1 \mathrm{~N}$ yang digunakan penitaran contoh $(\mathrm{mL})$

$\mathrm{V}_{2}=$ Volume $\mathrm{HCl}$ yang dipergunakan penitaran blanko $(\mathrm{mL})$

$\mathrm{N}=$ Normalitas $\mathrm{HCl}$

$6,25=$ Faktor konversi untuk protein daging

$14,008=$ Bobot atom Nitrogen

\section{Analisis data}

Data yang diperolehdilanjutkan dengan analisis variansi (anava). Berdasarkan analisis variansi, jika $F_{\text {hitung }}>\mathrm{F}_{\text {tabel }}$ pada tingkat kepercayaan 95\%, berarti hipotesis ditolak,dan apabila $F_{\text {hitung }}<\mathrm{F}_{\text {tabel }}$ maka hipotesis diterima dilanjutkan dengan DMRT (Duncan's Multiple Range Test) (Ansori, 2002).

\section{Asumsi}

1. Tingkat kesegaran ikan sebelum perlakuan dianggap sama.

2. Tingkat keterampilan peneliti selama penelitian dianggap sama.

3. Tingkat keterampilan panelis dalam melakukan penilaian dianggap sama.

4. Campuran biji kluwak yang dilumurkan dianggap sama.

\section{HASIL DAN PEMBAHASAN}

\section{Nilai organoleptik}

Berdasarkan hasil penilaian organoleptik yang dilakukan oleh 10 orang panelis tidak terlatih terhadap nilai rupa, bau, tekstur dan rasa pada ikan patin jambal siam yang diawetkan dengan biji kluwak selama penyimpanan pada suhu kamar diperoleh data sebagai berikut.

\section{Nilai organoleptik rupa}

Darihasil penelitian terhadap nilai organoleptik rupa ikan patin jambal siam yang diawetkan dengan biji kluwak pada konsentrasi yang berbeda terjadi penurunan obijai rupa selama penyimpan pada suhu kamar

Nilai organoleptik rupa ikan patin jambal siam yang diawetkan dengan biji kluwak selama penyimpanan pada suhu kamar pada perlakuan $\mathrm{P}_{3}$ (biji kluwak 6\%) memiliki nilai tertinggi dengan ciri-ciri rupa utuh, tidak cacat, warna kurang cemerlang dan kulit melekat pada daging $(4,25)$. Pada perlakuan $\mathrm{P}_{2}$ (biji kluwak 4\%) ikan patin jambal siam memiliki ciri-ciri rupa utuh, tidak cacat, warna kurang cemerlang dan kulit melekat pada daging $(4,14)$. Pada 
perlakuan $\mathrm{P}_{1}$ (biji kluwak 2\%) ikan patin jambal siam memiliki ciri-ciri rupa sedikit cacat, warna agak kusam, dan kulit melekat pada daging $(2,96)$. Pada perlakuan $\mathrm{P}_{0}$ (biji kluwak 0\%) ikan patin jambal siam memiliki ciri-ciri rupa kondisi agak rusak, suram dan kulit tidak melekat pada daging $(2,18)$. Untuk lebih jelasnya mengenai perubahan nilai rupa ikan patin jambal siam selama penyimpanan pada suhu kamar dapat dilihat pada Gambar 1.

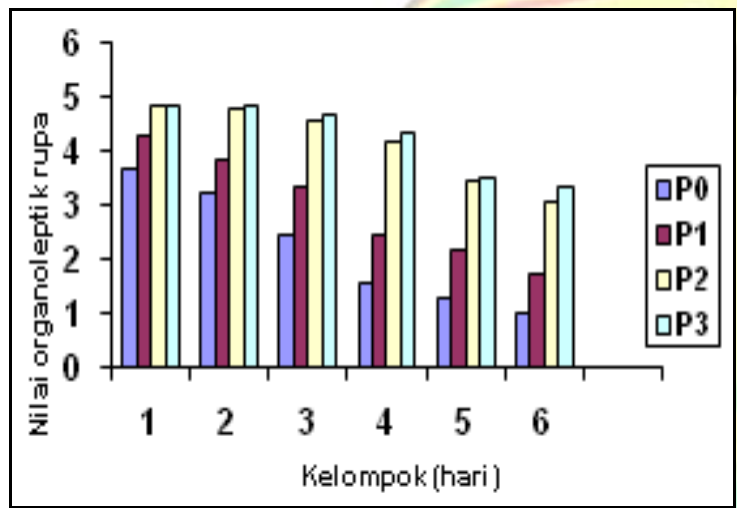

Gambar 1:Diagram rata-rata nilai rupa pada ikan patin jambal siam yang diawetkan dengan biji kluwak pada konsentrasi berbeda yang disimpan pada suhu kamar.

Keterangan:

$\mathrm{P}_{0}=$ Biji kluwak 0\% $\mathrm{P}_{2}=$ Biji kluwak 4\%

$\mathrm{P}_{1}=$ Biji kluwak 2\% $\mathrm{P}_{3}=$ Biji kluwak 6\%

Dari Gambar 1, terlihat bahwa semakin tinggi konsentrasi kluwak yang digunakan maka semakin tinggi nilai organoleptik rupa ikan patin jambal siam, tetapi semakin lama penyimpanan maka nilai organoleptik rupa semakin menurun. Berdasarkan hasil penelitian ikan patin jambal siam yang diberi perlakuan $\mathrm{P}_{3}$ (biji kluwak $6 \%$ )memiliki nilai rupa yang tertinggi pada awal penyimpanan yaitu 4,86 dan pada penyimpanan hari ke 6 yaitu 3,34. Ikan patin jambal siam yang diberi perlakuan $\mathrm{P}_{0}$ memiliki nilai terendah yaitu 3,69 pada awal penyimpanan dan pada penyimpanan hari ke 6 yaitu 1,00.
Berdasarkan

analisis

variansi menunjukkan bahwa ikan patin jambal siam yang diawetkan dengan biji kluwak memberi pengaruh nyata terhadap nilai organoleptik rupa ikan patin jambal siam segar. Hal ini terlihat dari Fhit $(71,86)>$ Ftab $(3,29)$ pada taraf kepercayaan 95\%, maka hipotesis ditolak, untuk melihat perbedaan tersebut maka dilanjutkan dengan uji DMRT (Duncan's Multiple Range Test). Hasil uji DMRT menunjukkan bahwa nilai rupa perlakuan $\mathrm{P}_{3}$, dan $\mathrm{P}_{2}$ berbeda nyata dengan perlakuan $\mathrm{P}_{0}$ dan $\mathrm{P}_{1}$.

\section{Nilai organoleptik bau}

Darihasil penelitian terhadap nilai organoleptik bau ikan patin jambal siam yang diawetkan dengan biji kluwak pada konsentrasi yang berbeda terjadi penurunan nilai organoleptik bau selama penyimpan pada suhu kamar

Nilai organoleptik bau ikan patin jambal siam yang diawetkan dengan biji kluwak selama penyimpanan pada suhu kamar perlakuan $\mathrm{P}_{2}$ (biji kluwak 4\%) memiliki nilai tertinggi dengan ciri-ciri bau spesifik ikan jambal siam segar jenis netral $(4,00)$. Pada perlakuan $\mathrm{P}_{3}$ (biji kluwak 6\%) ikan patin jambal siam memiliki ciri-ciri bau spesifik ikan patin jambal siam segar jenis netral $(3,82)$. Pada perlakuan $\mathrm{P}_{1}$ (biji kluwak 2\%) ikan patin jambal siam memiliki ciri-ciri mulai timbul bau ammonia $(2,65)$. Pada perlakuan $\mathrm{P}_{0}$ ( biji kluwak 0\%) ikan patin jambal siam memiliki ciri-ciri bau busuk lanjut dan bau asam sulfida $(1,84)$. Untuk lebih jelasnya mengenai perubahan nilai bau ikan patin jambal siam selama penyimpanan pada suhu kamar dapat dilihat pada Gambar 2. 


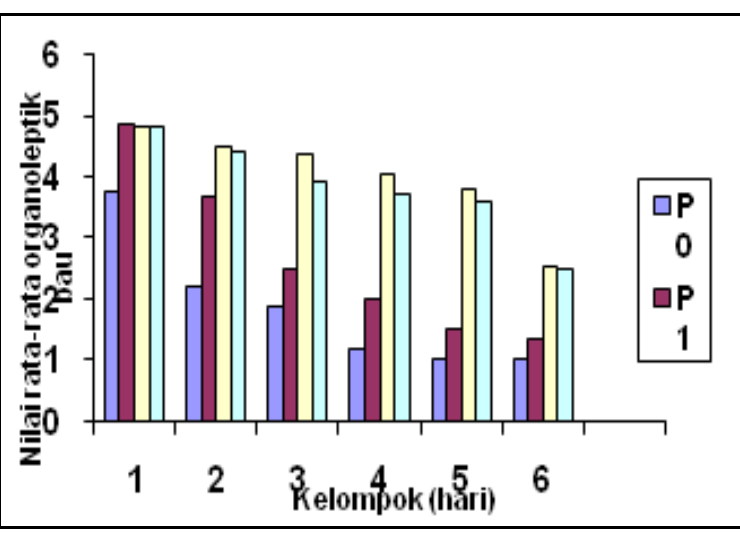

Gambar 2 Diagram rata-rata nilai bau pada ikan patin jambal siam yang diawetkan dengan biji kluwak pada konsentrasi berbeda yang disimpan pada suhu kamar. Keterangan:

$\mathrm{P}_{0} \quad=$ Biji kluwak 0\% $\quad \mathrm{P}_{2}=$ Biji kluwak 4\%

$\mathrm{P}_{1}=$ Biji kluwak 2\% $\mathrm{P}_{3}=$ Biji kluwak 6\%

Dari Gambar 2, terlihat bahwa nilai bau ikan patin jambal siam mengalami penurunan seiring dengan lamanya penyimpanan. Berdasarkan hasil penelitian ikan patin jambal siam pada awal penyimpanan yang diberi perlakuan $P_{1}$ memiliki nilai bau tertinggi yaitu 4,87 dibandingkan dengan $\mathrm{P}_{2}$ yaitu memiliki nilai bau 4,81, tetapi pada penyimpanan hari ke 6 $\mathrm{P}_{1}$ memiliki nilai bau yaitu 1,36 , ini lebih rendah dari $\mathrm{P}_{2}$ yang memiliki nilai bau 2,55. Sedangkan ikan patin jambal siam yang diberi perlakuan $\mathrm{P}_{0}$ memiliki nilai bau terendah yaitu 3,77 pada awal penyimpanan dan pada penyimpanan hari ke 6 yaitu 1,00.

Berdasarkan analisis variansi menunjukkan bahwa ikan patin jambal siam yang diawetkan dengan biji kluwak memberi pengaruh nyata terhadap nilai bau ikan patin jambal siam segar. Hal ini terlihat dari Fhit $(30,73)>$ Ftab $(3,29)$ pada taraf kepercayaan 95\%, maka hipotesisditolak untuk melihat perbedaan tersebut maka dilanjutkan dengan uji DMRT (Duncan's Multiple Range Test).

Hasil uji DMRT menunjukkan bahwa nilai bau perlakuan $\mathrm{P}_{2}$ berbeda nyata dengan perlakuan $\mathrm{P}_{0}$ dan $\mathrm{P}_{1}$, tetapi tidak berbeda nyata dengan perlakuan $\mathrm{P}_{3}$.

\section{Nilai organoleptik tekstur}

Darihasil penelitian terhadap nilai organoleptik tekstur ikan patin jambal siam yang diawetkan dengan biji kluwak pada konsentrasi yang berbeda terjadi penurunan nilai tekstur selama penyimpan pada suhu kamar Nilai organoleptik tekstur ikan patin jambal siam yang diawetkan dengan biji kluwak selama penyimpanan pada suhu kamar perlakuan $\mathrm{P}_{3}$ (biji kluwak 6\%) memiliki nilai tertinggi dengan ciri-ciri tekstur kompak, kurang padat, dan kurang elastis $(4,16)$. Pada perlakuan $\mathrm{P}_{2}$ (biji kluwak 4\%) ikan jambal siam memiliki ciriciri tekstur kompak, kurang padat, dan kurang elastis (4,09). Pada perlakuan $\mathrm{P}_{1}$ (biji kluwak 2\%) ikan jambal siam memiliki ciriciri tekstur kurang kompak, agak rapuh dan kurang elastis $(2,92)$. Pada perlakuan $\mathrm{P}_{0}$ (biji kluwak 0\%) ikan patin jambal siam memiliki ciri-ciri tekstur hancur, rapuh dan tidak elastis $(2,21)$. Untuk lebih jelasnya mengenai perubahan nilai tekstur ikan patin jambal siam selama penyimpanan pada suhu kamar dapat dilihat pada gambar 3.

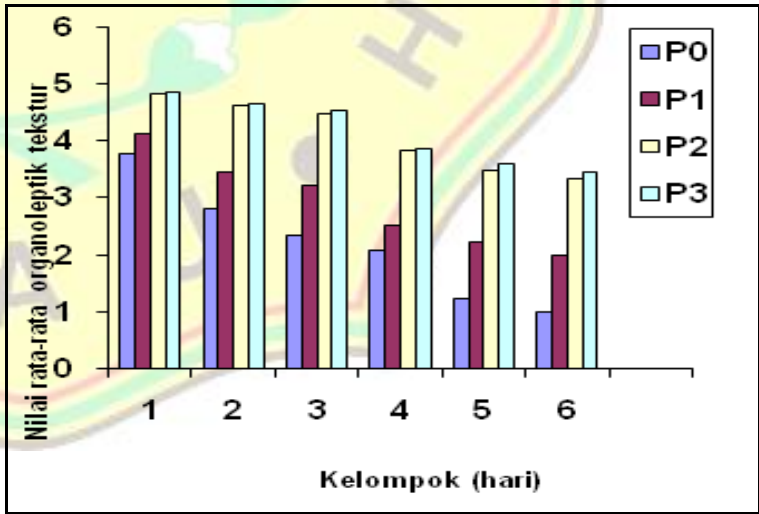

Gambar 3 Diagram rata-rata nilai tekstur pada ikan patin jambal siam yang diawetkan dengan biji kluwak pada konsentrasi berbeda yang disimpan pada suhu kamar.

Keterangan:
$\begin{array}{lll}\mathrm{P}_{0}=\text { Biji kluwak 0\% } & \mathrm{P}_{2}=\text { Biji kluwak 4\% } \\ \mathrm{P}_{1}=\text { Biji kluwak 2\% } & \mathrm{P}_{3}=\text { Biji kluwak 6\% }\end{array}$

Dari Gambar 3, terlihat bahwa semakin tinggi konsentrasi kluwak maka nilai tekstur 
ikan jambal siam semakin tinggi, tetapi semakin lama penyimpanan nilai tekstur semakin menurun. Berdasarkan hasil penelitian ikan jambal siam yang diberi perlakuan $\mathrm{P}_{3}$ memiliki nilai tekstur tertinggi pada awal penyimpanan yaitu 4,87 dan pada penyimpanan hari ke 6 yaitu 3,45. Sedangkan ikan jambal siam yang diberi perlakuan $\mathrm{P}_{0}$ memiliki nilai tekstur terendah yaitu 3,79 pada awal penyimpanan dan pada penyimpanan hari ke 6 yaitu 1,00.

Berdasarkan analisis variansi menunjukkan bahwa ikan patin jambal siam yang diawetkan dengan biji kluwak memberi pengaruh nyata terhadap nilai tekstur ikan patin jambal siam segar. Hal ini terlihat dari Fhit $(93,80)>$ Ftab $(3,29)$ pada taraf kepercayaan $95 \%$, maka hipotesisditolak untuk melihat perbedaan tersebut maka dilanjutkan dengan uji DMRT (Duncan's Multiple Range Test).

Hasil uji DMRT menunjukkan bahwa nilai tekstur perlakuan $\mathrm{P}_{3}$ tidak berbeda nyata dengan perlakuan $\mathrm{P}_{2}$, tetapi berbeda nyata dengan perlakuan $\mathrm{P}_{0}$ dan $\mathrm{P}_{1}$.

\section{Nilai organoleptik rasa}

Darihasil penelitian terhadap nilai organoleptik rasa ikan jambal siam yang diawetkan dengan biji kluwak pada konsentrasi yang berbeda terjadi penurunan nilai rasa selama penyimpan pada suhu kamar

Nilai rasa ikan patin jambal siam yang diawetkan dengan biji kluwak selama penyimpanan pada suhu kamar perlakuan $\mathrm{P}_{2}$ (biji kluwak 4\%) memiliki nilai tertinggi dengan ciri-ciri rasa kurang enak spesifik rasa ikan jambal siam segar $(3,87)$. Pada perlakuan $\mathrm{P}_{3}$ (biji kluwak 4\%) ikan patin jambal siam memiliki ciri-ciri rasa kurang enak spesifik rasa ikan patin jambal siam segar $(3,64)$. Pada perlakuan $\mathrm{P}_{1}$ (biji kluwak $2 \%)$ ikan patin jambal siam memiliki ciri- ciri rasa tidak enak, rasa tambahan mengganggu $(2,30)$. Pada perlakuan $\mathrm{P}_{0}$ (biji kluwak 0\%) ikan patin jambal siam memiliki ciri-ciri rasa tidak enak, rasa tambahan mengganggu $(2,02)$. Untuk lebih jelasnya mengenai perubahan nilai rasa ikan patin jambal siam selama penyimpanan pada suhu kamar dapat dilihat pada Gambar 4.

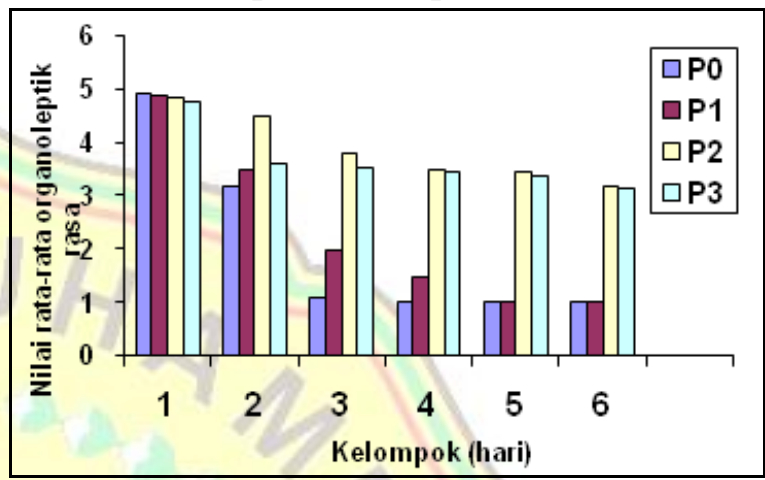

Gambar 4 Diagram rata-rata nilai rasa pada ikan patin jambal siam yang diawetkan dengan biji kluwak pada konsentrasi berbeda yang disimpan pada suhu kamar.

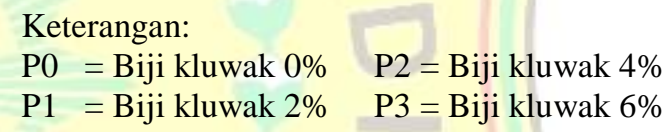

Pada Gambar 4, terlihat bahwa nilai organoleptik rasa ikan jambal siam mengalami penurunan seiring dengan lamanya penyimpanan. Pada awal penyimpanan ikan jambal siam yang diberi perlakuan $\mathrm{P}_{0}$ memiliki nilai tekstur tertinggi yaitu 4,90 tetapi memiliki nilai rasa terendah pada akhir penyimpanan yaitu 1,00. Sedangkan ikan patin jambal siam yang diberi perlakuan $\mathrm{P}_{2}$ memiliki nilai rasa terbaik yaitu rata-rata 3,87 .

Berdasarkan analisis variansi menunjukkan bahwa ikan patin jambal siam yang diawetkan dengan biji kluwak memberi pengaruh nyata terhadap nilai rasa ikan patin jambal siam segar. Hal ini terlihat dari Fhit $(13,16)>$ Ftab $(3,29)$ pada taraf kepercayaan 95\%, maka hipotesisditolak untuk melihat perbedaan tersebut maka 
dilanjutkan dengan uji DMRT (Duncan's Multiple Range Test).

Hasil uji uji DMRT menunjukkan bahwa nilai rasa perlakuan $\mathrm{P}_{0}$ tidak berbeda nyata dengan perlakuan $\mathrm{P}_{1}$ tetapi berbeda nyata dengan perlakuan $\mathrm{P}_{2}$ dan $\mathrm{P}_{3}$.

\section{Nilai kadar protein (\%)}

Darihasil penelitian terhadap nilai kadar protein dari ikan patin jambal siam yang diawetkan dengan biji kluwak pada konsentrasi yang berbeda dapat dilihat pada

Nilai kadar protein pada ikan patin jambal siam yang diawetkan dengan biji kluwak selama penyimpanan pada suhu kamar pada perlakuan $\mathrm{P}_{3}$ (biji kluwak 6\%) memiliki nilai kadar protein tertinggi yaitu $7,04 \%$. Pada perlakuan $\mathrm{P}_{2}$ (biji kluwak $4 \%$ ) memiliki nilai kadar protein $6,63 \%$. Pada perlakuan $\mathrm{P}_{1}$ (biji kluwak 2\%) memiliki nilai kadar protein $5,00 \%$. Pada perlakuan $\mathrm{P}_{0}$ (biji kluwak 0\%) memiliki nilai kadar protein $3,63 \%$.Untuk lebih jelasnya mengenai perubahan nilai kadar protein pada ikan jambal siam selama penyimpanan pada suhu kamar dapat dilihat pada Gambar 5.

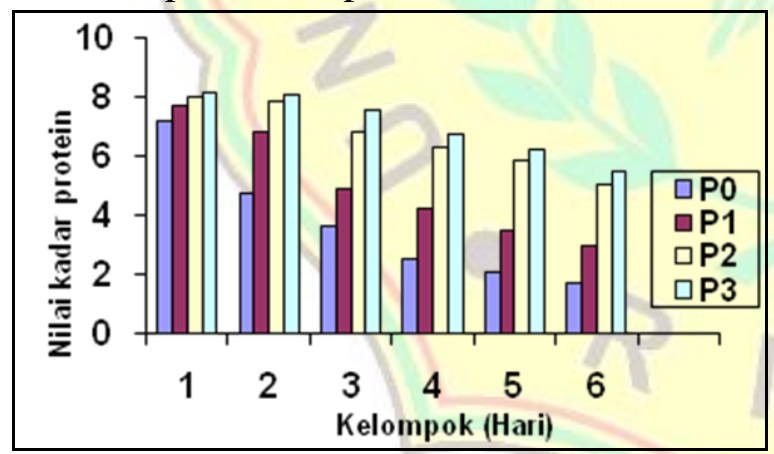

Gambar 5 Diagram nilai kadar protein pada ikan patin jambal siam yang diawetkan dengan biji kluwak pada konsentrasi berbeda yang disimpan pada suhu kamar.

Keterangan:

$\mathrm{P} 0=$ Biji kluwak 0\% $\quad \mathrm{P} 2=$ Biji kluwak 4\%

$\mathrm{P} 1=$ Biji kluwak $2 \% \quad \mathrm{P} 3=$ Biji kluwak $6 \%$

Pada Gambar 5 terlihat bahwa nilai kadar protein pada ikan patin jambal siam mengalami penurunan seiring dengan lamanya penyimpanan. Pada awal penyimpanan ikan patin jambal siam yang diberi perlakuan $\mathrm{P}_{3}$ memiliki nilai kadar protein tertinggi yaitu $8,18 \%$ dan pada penyimpanan hari ke 6 yaitu $5,48 \%$. Sedangkan ikan patin jambal siam yang diberi perlakuan $\mathrm{P}_{0}$ memiliki nilai kadar protein terendah yaitu $7,17 \%$ dan pada penyimpanan hari ke 6 yaitu 1,68\%.

Berdasarkan analisis variansi menunjukkan bahwa ikan patin jambal siam yang diawetkan dengan biji kluwak memberi pengaruh nyata terhadap nilai kadar protein pada ikan patin jambal siam segar, untuk melihat perbedaan tersebut maka dilanjutkan dengan uji DMRT (Duncan's Multiple Range Test).

Hasil uji DMRT menunjukkan bahwa nilai kadar protein pada perlakuan $\mathrm{P}_{3}$ tidak berbeda nyata dengan $P_{2}$, tetapi berbeda nyata dengan $\mathrm{P}_{0}$ dan $\mathrm{P}_{1}$.

\section{Nilai Organoleptik}

\section{Nilai organoleptik rupa}

Rupa memiliki peranan yang sangat penting dalam penyajian suatu produk khususnya makanan. Rupa merupakan salah satu parameter organoleptik yang penting karena merupakan faktor yang pertama kali dilihat oleh konsumen saat melihat suatu produk dan umumnya konsumen cenderung memilih produk yang memiliki rupa yang utuh, tidak cacat, warna cemerlang dan kulit melekat pada daging (Rustamaji, 2009).

Dari hasil uji rupa, terlihat bahwa dengan semakin tingginya konsentrasi biji kluwak yang diberikan maka semakin tinggi juga nilai rupa hal ini disebabkan oleh sifat antimikroba yang terkandung dalam kluwak yang mampu mengawetkan ikan patin jambal siam, namun semakin lama penyimpanan nilai rupa ikan patin jambal siam semakin menurun. Hal ini diduga karena terjadinya kerusakan lemak dalam daging ikan selama penyimpanan. 
Kerusakan lemak terjadi karena lemak pada ikan bergabung secara fisik dengan oksigen di udara dan membentuk peroksida. Proses ini dikenal sebagai oksidasi lemak, sehingga menimbulkan bau tengik yang tidak diinginkan dan perubahan rupa pada ikan (Rustamaji, 2009).

Menurut Winarno (1984) dalam Rustamaji (2009), perlakuan fisik dan kimiawi dari suatu bahan pangan dapat disebabkan pertumbuhan organisme yang mengakibatkan rusaknya struktur bahan pangan menjadi lunak dan berair sehingga penampakannya tidak cemerlang. Perubahan rupa atau warna disebabkan oleh rusaknya protein mioglobin yang akan membebaskan pigmen hemin, sehingga hemin berubah menjadi warna coklat karena teroksidasi.

Dari hasil penelitian terlihat bahwa pada penyimpanan hari pertama pada $\mathrm{P}_{0}$ (biji kluwak 0\%) ikan patin jambal siam memiliki ciri-ciri rupa utuh, tidak cacat, warna kurang cemerlang dan kulit melekat pada daging $(3,69)$. Pada perlakuan $\mathrm{P}_{1}$ (biji kluwak 2\%) memiliki ciri-ciri rupa utuh, tidak cacat, warna kurang cemerlang dan kulit melekat pada daging $(4,30)$. Pada perlakuan $\mathrm{P}_{2}$ (biji kluwak 4\%) ikan patin jambal siam memiliki ciri-ciri rupa utuh, tidak cacat, warna cemerlang dan kulit melekat pada daging $(4,84)$. Pada $\mathrm{P}_{3}$ (biji kluwak 4\%) ikan patin jambal siam memiliki ciri-ciri rupa utuh, tidak cacat, warna cemerlang dan kulit melekat pada daging $(4,86)$.Pada penyimpanan hari ke 3 dan ke 4 ikan dengan perlakuan $\mathrm{P}_{0}$ dan $\mathrm{P}_{1}$ kondisinya agak rusak, warna suram dan kulit tidak melekat pada daging sedangkan ikan yang diberi perlakuan $\mathrm{P}_{2}$ dan $\mathrm{P}_{3}$ kondisinya utuh, tidak cacat, warna kurang cemerlang dan kulit melekat pada daging. Pada penyimpanan hari ke 5 dan 6 ikan yang diberi perlakuan $\mathrm{P}_{2}$ dan $\mathrm{P}_{3}$ sedikit cacat, warna agak kusam, dan kulit melekat pada daging.

Berdasarkan hasil penelitian terhadap nilai rupa ikan jambal siam yang diawetkan dengan biji kluwak hanya mampu bertahan selama 4 hari penyimpanan. Perlakuan $\mathrm{P}_{3}$ (biji kluwak 6\%) memiliki nilai rupa tertinggi tetapi tidak berbeda nyata dengan perlakuan $\mathrm{P}_{2}$.

\section{Nilai organoleptik bau}

Dari hasil uji organoleptik bau, ikan yang diawetkan dengan kluwak hanya mampu bertahan selama 4 hari penyimpanan, ikan dengan perlakuan $\mathrm{P}_{2}$ memiliki nilai bau tertinggi dibandingkan dengan ikan pada perlakuan $\mathrm{P}_{0}, \mathrm{P}_{1}$, dan $\mathrm{P}_{3}$. Hal ini disebabkan perlakuan $\mathrm{P}_{2}$ mampu mempertahankan mutu ikan patin jambal siam, selain itu diduga bahwa dengan konsentrasi kluwak 4\% tidak menyebabkan bau tambahan pada ikan. Menurut Hangesti, 2006 bau yang muncul paling dominan berasal dari ikan, bukan dari bahan kluwak saja.

Menurut Afrianto (1989) setelah ikan mati, enzim masih mempunyai kemampuan untuk bekerja secara aktif. Namun sistem kerja enzim tidak terkontrol karena organ pengontrol tidak berfungsi lagi. Akibatnya enzim dapat merusak organ tubuh ikan. Peristiwa ini disebut autolisis dan berlangsung setelah ikan melewati fase rigormortis.Ciri terjadinya perubahan secara autolisis ini adalah terbentuknya bau busuk dari senyawa $\mathrm{H}_{2} \mathrm{~S}, \mathrm{NH}_{3}$ sebagai hasil akhir penguraian protein dan lemak. Bau busuk ini semakin nyata dengan semakin berlanjutnya pembusukan. Oleh sebab itu, semakin meningkat jumlah mikroorganisme yang terdapat pada bahan pangan maka semakin nyata perubahan bau, karena proses autolisis merupakan media yang sangat cocok untuk pertumbuhan bakteri. 


\section{Nilai organoleptik tekstur}

Tekstur merupakan salah satu faktor yang mempengaruhi pilihan konsumen terhadap suatu produk pangan. Tekstur merupakan sekelompok sifat fisik yang ditimbulkan oleh elemen struktural bahan pangan yang dapat dirasakan. Tekstur daging biasanya dipaparkan dalam istilah kelunakan pada saat disentuh dengan jari oleh panelis (Rustamaji, 2009).

Menurut Afrianto (1989) reaksi autolisis akan berlangsung setelah ikan melewati fase rigormortis. Reaksi autolisis merupakan proses penguraian protein dan lemak oleh enzim protease dan lipase yang terdapat didalam daging ikan. Biasanya proses autolisis akan selalu diikuti dengan meningkatnya jumlah bakteri, serta menyebabkan perubahan rasa, tekstur, dan rupa pada ikan. Proses autolisis merupakan media yang cocok untuk pertumbuhan bakteri

Berdasarkan hasil penelitian nilai tekstur ikan patin jambal siam mengalami penurunan selama penyimpanan. Perlakuan $\mathrm{P}_{3}$ memiliki nilai tertinggi selama penyimpanan dibandingkan dengan ikan yang diberi perlakuan $\mathrm{P}_{0}, \mathrm{P}_{1}$, dan $\mathrm{P}_{2}$. Hal ini diduga perlakuan $\mathrm{P}_{3}$ dengan konsentrasi picung 6\% mampu mempertahankan tekstur ikan selama penyimpanan 4 hari.

\section{Nilai rasa}

Rasa merupakan faktor yang sangat penting dan merupakan keputusan akhir konsumen menerima atau menolak suatu makanan walaupun parameter penilaian yang baik, tetapi jika rasanya tidak enak atau tidak disukai maka produk akan ditolak. Rasa menunjang peranan penting dari keberadaan suatu produk. Rasa ini dapat dipengaruhi oleh beberapa faktor diantaranya jumlah garam yang ditambahkan, bumbu-bumbu, gula dan lemak/minyak setelah produk dimasak/digoreng rasa akan muncul (Hangesti, 2006). Oleh karena itu dalam penelitian ini ikan patin jambal siam yang diberi perlakuan pada pengujian organoleptik terhadap rasa sebelum disajikan ikan terlebih dahulu dimasak dengan cara pengukusan selama 20 menit.

Berdasarkan hasil penelitian terlihat bahwa nilai rasa ikan patin jambal siam selama penyimpanan mengalami penurunan. Perubahan cita rasa bahan pangan disebabkan oleh penguraian protein, lemak, karbohidrat melalui proses kimiawi yang terjadi akibat reaksi enzimatik (Rustamaji, 2009).

Dari hasil uji rasa ikan yang diawetkan dengan kluwak dengan perlakuan $\mathrm{P}_{2}$ memiliki nilai tertinggi, hal ini diduga dengan konsentrasi kluwak $4 \%$ selain mampu mempertahankan mutu ikan juga tidak menimbulkan rasa tambahan yang mengganggu pada ikan, dibandingkan perlakuan $\mathrm{P}_{3}$ dengan konsentrasi kluwak $6 \%$ mampu mempertahankan mutu, namun menimbulkan rasa tambahan yang mengganggu rasa ikan, hal ini disebabkan tingginya konsentrasi kluwak yang diberikan.

\section{Nilai kadar protein}

Berdasarkan hasil penelitian dapat terilihat bahwa seiring dengan lamanya waktu penyimpanan, nilai gizi protein yang terkandung dalam tubuh ikan patin jambal siam pada perlakuan $\mathrm{P}_{2}$ dan $\mathrm{P}_{3}$ mengalami penurun, ini disebabkan oleh sifat antibakteri yang ada pada kluwak tidak mampu lagi menghambat pertumbuhan mikroorganisme pembusuk.

Proses penguraian protein terjadi akibat adanya penurunan $\mathrm{pH}$ jaringan otot pada daging ikan karena terbentuknya asam laktat. Nilai $\mathrm{pH}$ yang rendah dengan bantuan ATP akan menyebabkan aktin dan miosin 
yang keduanya merupakan protein miofibril akan bergabung membentuk aktomiosin yang relatif mudah mengalami penguraian. Hal ini menyebabkan terjadinya peristiwa rigormortis (kekakuan). Setelah melewati fase rigormortis, ikan akan melewati proses autolisis. Proses autolisis akan selalu diikuti dengan meningkatnya jumlah bakteri karena semua hasil penguraian oleh enzim (lipase dan protease) selama proses autolisis merupakan media yang cocok untuk pertumbuhan mikroorganisme. Akibat serangan bakteri, ikan mengalami berbagai perubahan yaitu lendir menjadi pekat bergetah, amis, mata terbenam dan insang berubah warna dengan susunan tidak teratur dan bau busuk (Rustamaji, 2009).

\section{KESIMPULAN}

Hasil penelitian menunjukkan bahwa keempat taraf perlakuan yakni $\mathrm{P}_{0}$ (biji kluwak 0\%), $\mathrm{P}_{1}$ (biji kluwak 2\%), $\mathrm{P}_{2}$ (biji kluwak 4\%) dan $\mathrm{P}_{3}$ (biji kluwak 6\%) berpengaruh nyata terhadap nilai organoleptik (rupa, bau, tekstur, dan rasa), serta nilai kadar gizi protein yang terkandung dalam daging ikan yang disimpan selama 6 hari pada suhu kamar.

Perlakuan $\mathrm{P}_{3}$ (biji kluwak 6\%) pada penyimpanan hari ke 4 menunjukkan nilai rupa yaitu 4,32 , nilai bau yaitu 3,73 , nilai tekstur 3,86, nilai rasa yaitu 3,45, serta memiliki nilai kadar protein yaitu $6,74 \%$. Pada perlakuan $\mathrm{P}_{2}$ (biji kluwak 4\%) memiliki nilai rupa yaitu 4,17 , nilai bau yaitu 4,04, nilai tekstur yaitu 3,84 , nilai rasa yaitu 3,50 serta memiliki nilai kadar protein yaitu $6,30 \%$.

Berdasarkan hasil analisis variansi DMRT (Duncan's Multiple Range Test) perlakuan $\mathrm{P}_{2}(4 \%$ biji kluwak dan garam $2 \%)$ dan $\mathrm{P}_{3}$ (6\% biji kluwak dan garam $2 \%$ ) tidak berbeda nyata terhadap nilai organoleptik (rupa, bau, tekstur, dan rasa) serta nilai kadar protein, tetapi $\mathrm{P}_{2}$ dan $\mathrm{P}_{3}$ berbeda nyata dengan perlakuan $\mathrm{P}_{0}$ dan $\mathrm{P}_{1}$ $(\mathrm{P}<0,05)$, sehingga $\mathrm{P}_{2}$ adalah perlakuan terbaik yang mampu dalam mempertahankan mutu ikan patin setelah disimpan pada suhu kamar selama 4 hari.

\section{DAFTAR PUSTAKA}

Afrianto., dan Evi. 1989. Pengawet dan Pengolahan Ikan. Kanisius. Yogyakarta

Agustina, R. 2002. Pengaruh Pemberian Limbah Tauge Kacang Hijau (Vigna radiate (L) Wilczek) Terhadap Pertumbuhan dan Kandungan Zat Gizi Ikan Mas (Cyprinus carpio L.). IPB. Bogor

Amri, K., dan Khairuman. 2008. Buku Pintar Budi Daya 15 Ikan Konsumsi. Agro Media Pustaka. Jakarta

Ansori, A. 2002. Perancangan Percobaan. IPB Press. Bogor

Asrori, A. 2008. Efektivitas Penghambat Ekstrak Daging Biji Picung (Pangium edule Reinw) Terhadap Pertumbuhan Rhizoctonia sp. Secara In Vitro. IPB. Bogor

Bele, A., dan Varsha, M. 2010. Potential of Tannins: A Review. J.of Plant Sciences 9 (4):209-214

Dinas Perikanan dan Kelautan Propinsi Riau. 2007. Statistik Perikanan Tangkap Propinsi Riau. Pengembang Perikanan Tangkap-APBN. Pekanbaru

Dinas Perikanan dan Kelautan Propinsi Riau. 2010. Statistik Perikanan Tangkap Propinsi Riau. Pengembang Perikanan Tangkap-APBN. Pekanbaru

Ghufran, M. 2009. Budi Daya Perairan. Citra Aditya Bakti. Bandung

Gaspersz, V. 1991. Metode Perancangan Percobaan. Armico. Bandung

Hangesti, R. 2006. Pengaruh Pengawetan Menggunakan Biji Picung (Pangium edule Reinw) Terhadap Kesegaran dan 
Keamanan Ikan Kembung Segar (Rastrlliger brachysoma). IPB. Bogor

Husni, E. 2007. Pengawetan Ikan Segar dengan Menggunakan Biji Buah Kepayang (Pangium edule Reinw) dan Analisa secara Kualitatif. J.Sains Teknik Farmasi 12 (1)

Mangunwardoyo, W., Lily., dan Endang, S. 2008. Analisis Senyawa Bioaktif dari Ekstrak Biji Picung (Pangium edule Reinw) Segar. Berita Biologi 9 (3)

Nazmi, U. 2009. Analisa Protein, Kalsium, dan Lemak Pada Ikan Porapora.Universitas Sumatra Utara. Medan

Purwani, E., dan Muwakhidah. 2008. Efek Berbagai Pengawet Alami sebagai Pengganti/Formalin terhadap Sifat Organoleptik dan Masa Simpan Daging dan Ikan. Universitas Muhammadiyah Surakarta. Surakarta

Rustamaji. 2009. Aktivitas Enzim Katepsin dan Kolagenase dari Daging Ikan Bandeng (Chanos forskall) Selama Periode Kemunduran Mutu Ikan. ITB. Bogor

Standar Nasional Indonesia 01-2891. 1992. Cara Uji Makanan dan Minuman. Pusat
Standarisasi Nasional. Jakarta

Standar Nasional Indonesia 7474. 2009. Rendang Daging Sapi. Badan Standarisasi Nasional. Jakarta

Standar Nasional Indonesia 01-2729. 2006. Ikan Segar. Badan Standarisasi Nasional. Jakarta

Sudjana. 2005. Metoda Statistika. Tarsito Bandung. Bandung

Sukarti, T. 2011. The Use of Black Nut (Pangium edule Reinw) in Maintaining the Quality of Fresh Fish (Cyprinus carpio Linnaeus). UPI. Indonesia

Suryani. 2007. Teknologi Bioproses. Bung Hatta. Padang

Widaningrum., dan Christina, W. 2007. Kajian Pemanfaatan Rempah-rempah sebagai Pengawet Alami pada Daging. Balai Besar Penelitian dan Pengembangan Pascapanen Pertanian. Bogor

Winarno. 1991. Kimia Pangan dan Gizi. Gramedia Pusaka Utama. Jakarta

Yee, F., dan Yuen, K. 2009. Antioxidative and Antibacterial Activities of Pangium edule Seed Extracts. International Journal of Pharmacology 